\title{
The Saz as a Mode of Understanding Alevism
}

\author{
Iris Sibel Muradoglu ${ }^{1}$ * \\ 1 University of Leuven, Belgium \\ *iris.muradoglu@kuleuven.student.be
}

Received: 24 May 2017 ; Accepted: 29 September 2017 ; Published: 1 November 2017

Editor: Michael Viega Reviewer: Theresa Merrill

\begin{abstract}
An attempt to give insight into who Alevis are and what Alevism is, only further demonstrates the complexities that arise in doing so. However, this ambiguity is essential to discuss in terms of what this paper seeks to answer and that is: How can we comprehend the complexities of Alevism, using music and the saz as a mode of understanding that does not further reduce them to just representations of folklore? For those who identify as Alevis, music, and in particular the saz, play a central role in this formation of identity. Alevis in their religious rituals use music and dance, and thus their practices oppose that of a Sunni-majority Turkey. In this sense, when it comes to incorporating music in their religious traditions, the Turkish state undermines and therefore considers them illegitimate religious practices and deems them purely as cultural ones. Emphasizing the importance of the saz aims to bridge the cultural and religious implications of the instrument and thus metaphorically serve as also a bridge in understanding the complexities of defining Alevis. Contextualizing is imperative for understanding the performative piece at the end of the paper. This section aims to provoke the reader to think about what they have just read and listen to a piece composed by an Alevi saz player who was victim to one of the atrocities in Alevi history. The video is supplemented by the voices of my research participants who share their thoughts about the song-"Güle Yel Değdi"(Rose is Touched by the Breeze), the composer of the song-Hasret Gültekin, and about Alevism in general.
\end{abstract}

Keywords: Alevism, saz, bağlama, Alevis, music, Hasret Gültekin, Performance Studies, Musical instruments, Musical performance

\section{Alevis and Alevism "defined"}

Alevi means "follower of Ali" (Adams, 2016; Sels, 2014). Alevis, in a general sense, are difficult to define (Erol, 2012), which explains the vast and diverse definitions that can be found in the relevant literature. An explanation that takes a broader approach to dealing with what Alevism is can be seen in Erol's (2008) definition,

Alevism is a sense of belonging for the people who call themselves Alevis and who are recognized as Alevis by outsiders, namely Sunnis or non-Alevis, which they have constructed by considering what things are common to themselves and what the differences are between themselves and "other." (p. 151)

When discussing Alevism within a religious context, Dressler (2015) is wary against a definition that presents it as "clearly defined" and fitting in "bounded traditions" (p. 446). Instead, he proposes "understanding Alevism within a framework of overlapping 
and porous religious traditions (p. 446). On account of their history of having to maintain secrecy in their identity in order to avoid discrimination and persecution, they were unable to come up with a unified consensus on their rituals and the different interpretations of their rituals only adds to their diverse construction (Hanoğlu, 2016). In fact, the different thoughts and multiple ways in which Alevis are defined, not only by others but among each other and within themselves, can be seen as an "essential" part in who Alevis are (Sökefeld, 2004). Because I, too, hesitate to provide a condensed version of a definition, I have chosen to understand Alevism by tracing its history and looking at its relation within the tradition of Islam. What, I argue, does remain undeniable is the importance of music in Alevism, more specifically the centrality of the saz. Later on in this paper, I discuss further in detail the meaning of the saz for Alevis, how the saz can be seen as a unifying element in Alevism, and how its role in Alevism opposes common Muslim practices.

\section{Alevism throughout history \& within the tradition of Islam}

Whether one chooses to see Alevism as falling within the boundaries of Islam only within a heterodox sphere or "as a unique belief system" (Hanoğlu, 2016, p. 40), the fact remains that it is generally seen and understood through a lens that is Sunni Islam. Only after realizing this can we then begin to grasp their struggles and discrimination throughout history, which is a key part in understanding Alevis (Hanoğlu, 2016). This can be done by analyzing the relationship between Alevism and the Sunni Islamic tradition that is lived in Turkey.

The discourses that make up a tradition, or what is "the correct form and purpose of a given practice," forms its history (Asad, 2009, p. 20). Discussing Alevism using the concept Asad (2009) proposes, "Islam as a discursive tradition," enables us to contextualize Alevism within a historical period that helps us to understand the power struggles involved and how the accusations of Alevis being a heterodox group have changed over time. We can see that the past (Alevis' history in the Ottoman Empire and in the making of the Turkish Republic) and the future of Alevism (how Alevism is lived and continues to be lived in Turkey and how it is maintained in the diaspora) is related to its present (how is Alevism defined and where does it belong in Islam and in Turkey).

The fact that Alevism is deemed as heterodox is an important point to bring forth. Despite seeing the term heterodox as being "out of place in Islamic studies ${ }^{1}$," Langer and Simon (2008) acknowledge its potential usefulness when ascribing it to power when they state, "it is not only political power that puts a religious authority in the position of orthodoxy, but religious authority also implies political power" (p. 281). Within the study of Islamic traditions, the notion of orthodoxy is crucial ${ }^{2}$ to understand. Orthodoxy, holds a specific "relationship of power to truth" and as Asad (2009) explains, "wherever Muslims have the power to regulate, uphold, require, or adjust correct practices, and to condemn, exclude, undermine, or replace incorrect ones, there is the domain of orthodoxy"3 (p. 22). Within a Sunni majority population and Sunni Islamic framework in Turkey (power), Alevis' lived experience is through this statement of orthodoxy (truth) and consequently their practices and rituals are considered illegitimate or heterodox. An example of this struggle between the majority Sunni Muslim thought and the Alevis' is seen in the following newspaper quote: "The Turkish government is seeking to meet the increasing demands of Alevis-a sect of Islam that differs significantly from the country's majority Sunni followers" but that "recognizing the Alevis as a branch of Islam, is heresy to many pious Sunni Muslims in Turkey" (Asia News Monitor, 2010).

To have a better understanding of the roots of this heterodox-orthodox power relationship we have to go back to the 16th century during the Ottoman Empire. This is the point in time where it "can be assumed...[to have form[ed]] the initial point of anti-Alevi attitudes, which have "survived" in the shape of rumors, prejudices and depreciatory judgements until today" (Karolewski, 2008, p. 438). In the mühimme defterleri (records of significant issues), decrees were created for those who showed support 
for the Safavid ${ }^{4}$ order, the Kızlbaş ${ }^{5}$ were among those who did, which the Ottomans saw as a direct threat to the Empire (Dressler, 2003; Erol, 2010; Koerbin, 2011b; Zarinebaf-Shahr, 1997). The Kızılbaş, were consequently amongst those targeted by the Ottoman Empire. The Ottoman Empire sought to persecute the Kizılbaş through religious justifications, as a result, "Kızılbaş were accused of heresy and even of unbelief" (Dressler, 2003, p. 112). One of the fetvas (decrees) ordered the murdering of the Kizilbas based on them being "infidels," "heretics," and "rebels" (Yildiz \& Verkuyten, 2011; Zarinebaf-Shahr, 1997). These accusations resulted in the persecution of the Kızılbass as well as terminal effects on the relationships between the communities in the villages (Zarinebaf-Shahr, 1997). Alevis reappear in the 19th century due to a flux in those coming to the Ottoman Empire, an especially relevant group being the Western Christian missionaries ${ }^{6}$ (Karolewski, 2008). After seeing the way Alevis lived their tradition and witnessing the division between those who were Sunni Muslims and the Kizllbaş, the visitors from the West, such as the Christian missionaries, labeled the practices of Alevis as "heterodox Islam" in analogy to the Christian usage of the word "heterodox"” (Karolewski, 2008, p. 435-436). The 20th century marks an important time for Alevis, a time where the Ottoman Empire ceases to exist and the Turkish Republic, which adopts a form of secularism, is established. When Turkey became a republic, under Mustafa Kemal Atatürk ${ }^{7}$, significant changes that drastically differed from the governing ways of the Ottoman Empire, such as doing away with sharia courts, were made (Şentürk, 2016). These actions were especially well received by Alevis (Şentürk, 2016; Yildiz \& Verkuyten, 2011). Alevis are strong supporters of secularism and a part of their "belief" goes into putting more trust into human agency, or "humanist thought," rather than in religious belief ${ }^{8}$ (Bates, 2011). However, secularism in Turkey fell short of delivering all that Alevis might have hoped, as "Sunni Islam was the undeclared religion of the new state" (Şentürk, 2016, p. 121). During the start of building Turkey as a unified nation, this idea already becomes apparent.

Looking at the period of Turkish nation-building, Markus Dressler (2013) points out that:

Within the discourse of early Turkish nationalism, the making of Alevism was directed against two polemics: first against the standard Ottoman anti-Kızllbaş rhetoric that marked the Alevis as heretics and justified their exclusion from the centers of Ottoman life, as well as occasionally also their persecution; and second, against a Western discourse that depicted Alevism as being strongly influenced by Christianity. Against these two sets of knowledge, Turkish nationalist writers underlined the Alevis' Turkishness and Islamic orientation, which they saw as a precondition for their integration into the Turkish nation. (p. 273)

In other words, to be accepted by the Turkish state, the hegemony reconfigured Alevism in a way that would fit within their vision of building the ideal nation-state, which resulted in the "folklorization" and "musealizing" of Alevism (Dressler, 2013, p. 279). From early on, Alevism as a religion was undermined and delegitimized. The Turkish nationalists' solution for successful "Turkification," was to reduce them to "carriers of ancient Turkish tradition," or representations of folklore (Dressler, 2013, p. 279).

Furthermore, Alevis, "within Turkey represent-for some Turks-a challenge to the hegemony of a Turkish culture in which Turkish, Sunni Islam and Ottoman identities are seen as completely and necessarily interwoven" (Ross, 2016, p. 253). Only with this in mind can we then begin to make sense of the positionality and requests of Alevis within Turkey today. In the eyes of the Turkish state, Alevi tradition does not qualify as a religious entity in and of its own (Atasoy, 2011). When Alevis fight this notion, such as in the case of challenging the section dedicated for religion on Turkish National Identification cards, they not only fail at obtaining this "right" to "self-definition" but directly "challenge the republican model" (Atasoy, 2011, p. 105). Despite the Alevis' efforts, the Turkish government still does not officially recognize cemevis ${ }^{9}$ as a place of worship (Lord, 2017; Yildiz \& Verkuyten, 2011). The religious authority in Turkey, 
which encompasses the ulama, denies their requests for receiving the same benefits as a mosque, and as such sees their "demands for the recognition of cemevis...as a threat to Islam, and thereby the nation" (Lord, 2017, p. 13). In all these cases, the perceptions of Alevis as a threat or challenge to the Turkish state and its ideals are further embedded into thought and perceived as real.

What is significant, though, is how Alevis have taken it upon themselves to re-negotiate the use of "Kızılbaş" and heterodox when referring to themselves. Alevis have gone back to describing themselves as "Kızlbaş" and have seemingly accepted the term heterodox as a way of description (Karolewski, 2008; Langer \& Simon, 2008), which "Alevi intellectuals" played a part in achieving ${ }^{10}$ (Langer \& Simon, 2008). Despite the negative connotations associated with Kızılbaş, they are turning it back into the positive title as they remember it (Karolewski, 2008). In using heterodox, they have reversed the role of who gets to use it, and as a result, have taken agency in describing themselves as different from Sunni Islam (as opposed to being told how they are different from Sunni Islam). In other words, "this power constellation turns, the heterodox can be self-determined in regard to their own tradition and aggressively use the term 'heterodox' to underline their own non-orthodox and therefore liberal and egalitarian tradition" (Karolewski, 2008, p. 456). Thus, Alevis can be seen as taking what has been ascribed to them by others, internalizing it, and reproducing and reflecting it in a positive light that benefits them and gives them the control of self-identification.

\section{The meaning of music \& the saz for Alevis}

Because of the nearly impossible nature of defining Alevism, I have chosen to focus on understanding Alevis or Alevism with or alongside, the musical instrument, the saz, (also known as bağlama ${ }^{11}$ ) . My intention is not to reduce Alevism to merely an instrument and thus fall into the trap of "folklorizing." The saz is undoubtedly at the heart of however one chooses to define Alevism, be it a religion of its own, a sect of Islam, an ethnicity, culture, etc. This particular musical instrument brings together elements that can be considered religious with aspects that lean towards being more cultural, and thus can create, and therefore manifest, what it means to be Alevi and what Alevism is. The significant role of music and the saz for Alevis is underscored in the statement made by Pinkert in the abstract of her doctoral dissertation (2016) which states, "Music is central to Alevi claims of ethnic and religious difference-singing and playing the bağlama (Turkish folk lute) constitutes an expressive practice in worship and everyday life."

Music undisputedly plays an integral role in the formation of Alevi identity and in their religous ceremony, cem and ritual dance, semah-with the bağlama at the core (Adams, 2016; Erol, 2010; Sels, 2014). The cem ceremony, is held in a cemevi and involves both music and dance within the ritual, as well as the presence and participation of both men and women (Bates, 2011; Erol, 2010; Sels, 2014). Alevis' use of music and dance in their religious rituals stands in opposition to the practices of "mainstream Sunni Islam"- thus, for the Turkish state, these rituals are not "regarded as legitimate religious practices" (Özkul, 2015, p. 83). Furthermore, Alevis do not adhere to many of the common Muslim practices ${ }^{12}$ such as visiting the mosque for prayers (instead they go to the cemevi), praying five times a day, or fasting during Ramadan (Bates, 2011; Sels, 2014). Furthermore, they do not abstain from drinking alcohol or playing music (Bates, 2011; Sels, 2014)—an important point for the purposes of this paper. In fact, they value music highly (Bates, 2011; Sels, 2014). Hanoğlu (2016), makes the point that, conversely, Muslims do not observe the practices that are central in Alevism.

Alevis are strong supporters of securalism and therefore hold Mustafa Kemal Atatürk in quite high regard, right alongside Pir Sultan Abdal ${ }^{13}$ and the saint Hacı Bektaş Veli ${ }^{14}$ (Bates, 2011; Dressler, 2003). Through Aş1 ${ }^{15}$ poetry and musical practices that are accompanied by the $s a z$, Aşıks ${ }^{16}$ often tell stories about these particular figures and use song as a way of conveying 'profane topics' (Dressler, 2003) or "political messages" (Bates, 2011) and their religious tradition (Dressler, 2003). The political messages they 
express are deeply embedded in their poems ${ }^{17}$. Much like how the religious and cultural expressions are intertwined with the playing of the saz, through analyzing poems, Dressler (2003) argues that in Alevism it is not possible to separate, or make a distinction, between religion and politics. For Alevis, both the "'religious' and the 'political' bear holy and profane characteristics" (p. 138). This is what I argue in relation to the saz, it has both religious and cultural meanings, or "holy and profane characteristics," and can hold a different meaning according to every Alevi.

In Adams' (2016) research, he asserts that in Turkey, "the bağlama has become a symbol and representation of Alevi social identity" (p. 45) and that "the instrument extends as not only a physical symbol of their religion, but also a figurative symbol of solidarity" (p. 52). Interestingly, the bağlama is also considered to be the national instrument of Turkey (arguably a symbol of the nation). Therefore, it is appropriate to apply Bates' (2012) claim that "instruments become such contested sites of meaning" (p. 369) to the case of the bağlama. These two different meanings become even more interesting when we consider the clash between the majority Sunni population in Turkey and the Alevis. The long, and often "politically-hostile," history between the majority Sunnis and Alevis in Turkey took a different direction with the rise in popularity of bağlama player Arif Sağ and the Alevi Revival of the 1990s that lead to the Alevi's emancipation (though discrimination still exists) (Adams, 2016). Alevis have become more open about sharing their identity with others, contrary to a time when they felt the need to hide this information (Sels, 2014). The bağlama amongst Alevis as a "figurative symbol of solidarity" (Adams, 2016, p. 52) also extends in the diaspora. In Erol's (2012) research on Alevis in Toronto, musical performances were a way "to foster community cohesion and to reflect on their relationship with their Alevi past" (p. 833). In the diaspora, being Alevi leans more towards having a "sociocultural and religious" statement rather than a "political" one such as the case in Turkey (Sels, 2014).

Another example from the diaspora comes from my fieldwork in Belgium. In my multi-sited ethnography, namely in Brussels, Antwerp, and Ghent, I attend various saz classes and use an emic approach to my research by not just observing the classes but actually performing and learning how to play the saz side-by-side the other students. Before I even began my research, I found that occasionally when I would tell Turkish people that I was learning to play the saz they would subsequently ask me if I was Ale$\mathrm{vi}^{18}$. This observation thus served as a main starting point when I began my research on the meaning of playing the saz in Belgium. According to Alevis, the saz is often called the telli koran (stringed Quran) (Sels, 2014), and this description is reiterated by my participants in my own fieldwork in Belgium and confirms the "sacred" nature of the saz in the eyes of Alevis (Bates, 2011). When asked why she is interested in playing the saz, one of my female Alevi saz participants explained that it was a part of her "[Alevi] culture" and that there has always been a saz in her home. Usually, she says, learning to play saz was something passed on by from another family member, but joked that after failed attempts to learn from her brother she turned to taking professional lessons. In my fieldwork site in Antwerp, one of my participants, a professional saz player, told a story about growing up and his father taking him to the cemevi for his saz classes. Upon hearing this story, I asked if he was Alevi then, to which he responded yes, but that he is not involved in the religious side of Alevism, but in only the musical, or saz, aspect of Alevism.

Music, playing the saz, and singing are much more than a form of expression for Alevis. The saz serves as a symbol, a peaceful weapon, for them to use against all the injustices and persecution they have faced throughout many years. Bates (2012), also mentions the saz as a weapon in relation to the familiar portrayal of Pir Sultan Abdal holding the saz with his two hands, directly above his head, "as if it were a rifle or sword" (p. 384). Bates (2012) continues this thought by expressing the following:

In the hands of Pir Sultan, the saz becomes a weapon against injustice and imperial oppression; he does not even need to play it for its effect to be felt...Pir Sultan Abdal implores us to believe that 'the saz is mightier than the sword.' (p. 384) 
However, this particular idea does not stop only with the imagery of Pir Sultan Adbdal. Alevis perpetuate and embody this notion through performance. Selma, a participant and good friend, further elaborates on the idea of regarding the saz as a weapon ${ }^{19}$ :

[The saz] is the sole means of defending themselves...[Alevis] are defending themselves with [the saz] because there would never be a weapon in their hand...we don't have any other thing to do it...if you stop playing the saz or singing, then the culture will die. Because it's such an important part of the culture itself, of the religion. So, if one day the saz stops playing in the world, it's all gone you know.

Music, thus, becomes a vital tactic for survival through means of oral transmission of their history and stories to future generations. When describing the meaning of what a single türkü can hold, my participants claim, "you can write an encyclopedia" from the information and "if you listen to the songs it's like reading a book." Singing and playing the saz can evoke memories of events in history, including tragedies such as the 1993 Sivas Massacre ${ }^{20}$, and be a way to commemorate the victims, such as Hasret Gültekin. One of my participants, Serkan, reflects on this:

[Güle Yel Değdi] reminds me of Hasret Gültekin, and because of this, the tragedy of the 1993 Sivas Madımak...this türkü, and all other türküs Hasret Gültekin performs reminds me of Sivas...the incident of Sivas, the savagery done that day, wasn't done only towards those people who were there. It was a massacre done to all Alevis, Alevis and the Alevi population have always been persecuted in these types of incidents.

When Serkan talks about how the massacre was not just done to those who were the victims, but to all Alevis, it touches upon the idea of "collective trauma" that Yildiz \& Verkuyten's (2011) use in their research about Alevis. The idea, essentially, means that whether one has experienced the trauma personally or not, a shared feeling is formed. This form of solidarity, due to "shared victimhood", can either counter in a more "violent" form or peaceful forms of solidarity (Yildiz \& Verkuyten, 2011). Using the saz as a weapon (as previously mentioned by one of my participants), can therefore be seen as a peaceful form of solidarity that is used as a counter to the injustices and violence inflicted on them.

Güle Yel Değdi by Hasret Gültekin was a song that we had learned to play in my fieldwork site in Brussels. Selma talked about how the song held a great deal of meaning to her. We were sitting in her living room, sazes in hand after just practicing, when she explained to me the story behind the song:

[The song], it has an expression because....Hasret Gültekin, who made this song, he died in Sivas. He was burned there. So, that already, playing this, is symbolic for me...it's nice to play his songs because they keep him alive somehow.

When I asked our Brussels saz teacher why he chose this song for us to play, he explains, "Introducing the pieces that [Hasret Gültekin] composed to the students or saz enthusiasts is far beyond important, but more like a duty for me...I made a promise to him." There is a certain "thread" that connects the songs to people. This circulation of remembrance is embedded in songs, for example, Hasretim Hasret (I am longing Hasret), a composition from my saz teacher's father as a way of remembering Hasret Gültekin.

I would, therefore, now invite the reader to finally engage with the video, a portion of the song Güle Yel Değdi. ${ }^{21}$ The video was taken Fall 2016, in my fieldwork site in Brussels, during one of our regular classes. My saz teacher sings, as the rest of us play along or simply listen (there are other students not within the shot of the video). I encourage you, the reader, as you are listening, to think about what has been written thus far. We learned this song quite early on in my fieldwork, before I had truly started to get in the depths of my research. After reading, researching, and writing about this topic, I look back at this song and listen to it with a different ear. How can providing a historical context help frame and change the way we listen to a certain song? How can other musical instruments be seen as symbols or metaphors? What other songs derive meanings that go beyond the lyrics? 


\begin{tabular}{|l|l|}
\hline \multicolumn{1}{|c|}{ Güle Yel Değdi Sözleri } & \multicolumn{1}{c|}{ Rose is Touched by the Breeze Lyrics } \\
\hline Güle Yel Değdi & Rose is touched by the breeze \\
Güneş Olursa & Only if there is a sun above \\
Cana Ten Değdi & Body is touched by the soul \\
Ateş Olursa & Only if there is fire \\
$\ldots$ & $\ldots$ \\
\hline
\end{tabular}

Including a brief, historical outline of the injustices and persecution that Alevis have faced throughout history and analyzing how just one song can carry so much meaning to an Alevi, permits a solid approach to listening to the song. It does not make sense to simply present the song and its meaning without telling the story that encompasses it. The words of the song, even though I have provided a translation, are not the most vital part of understanding how the song is meaningful—but the stories the song brings forth are. This leads to deeper understanding and greater appreciation when listening. It is bearing all this in mind, what was written in this brief article about Alevis and Alevism, while one is listening to this shortened version of the song.

\section{Conclusion}

Much of the same perceptions about Alevis in 16th century Ottoman Empire were brought into the making of the Turkish Republic and are even absorbed in the current atmosphere of present-day Turkey. In order to avoid essentializing and reducing it further to merely an image of Turkish folklore, I explore and engage in the understanding of Alevism with or alongside music and the saz, instead of through. Choosing to emphasize the saz serves as a way to see the complexities that arise when discussing their religious and cultural traditions as separate. In fact, it proves that the $s a z$ is an important element of both religion and culture, and to each Alevi, it has a unique meaning. Though the vast and diverse history that surrounds Alevis and Alevism goes beyond the scope of this paper, analyzing the historicity of Alevism in relation to the Ottoman Empire, in present-day Turkey, and within Islam, as well as bring in the meaning of music and playing the saz for Alevis, serves as the framework to contextualize the end performative piece, Güle Yel Değdi. Thus, allowing the reader to engage with the performative piece with a better knowledge base and be able to take away, a brief, yet enriched, understanding of Alevis.

\section{Notes}

1. Langer \& Simon (2008) state that the term "orthodoxy" has no "equivalent expression in Arabic" and that "the 'orthodoxy' versus 'heresy' scheme is denounced as a dichotomy of Eurocentric interpretive categories that fails to grasp the pluralism and complexity characteristic of Muslim religious life" (p. 273).

2. Dressler (2013) argues that "where normatively ambiguous concepts such as orthodoxy/ heterodoxy binary are used, they should be employed in a discursive manner as indicators of religio-political power relations within particular context" (p. 285-286).

3. According to Dressler (2013), the fact that Alevism's heterodoxy has been understood through the majority Sunni Muslim framework that had been "translated into secular discourse" was "not a paradox" but a part Turkish secularism that "is obsessed with regulating religion and therefore in need of a normative standard of correct religion (p. 277, emphasis my own).

4. The Safavid order was "the sufi tradition from which the Safavid dynasty had emerged" (Dressler, 2005, p. 152). 
5. Also written as "Kizilbash." This translates to "redheads," due to the red turbans that they wore (Erol, 2010; Zarinebaf-Shahr, 1997). Hanoğlu (2016) states that most Alevis have Kizilbash or Bektashi roots. Dressler (2003), states this is due to the "evidence that as early as the sixteenth century one branch of the Bektaşiye and some Kızllbaş-Alevi communities established institutional connections. These connections are still valid, which is one of the reasons why...Alevis and Bektaşis are often not distinguished" (p. 111).

6. Taş (2015) problematizes the representations of Alevis that the Christian missionaries gave. He analyzes the account given from one missionary in particular, Stephan van Rennselaer Trowbridge, who believed Alevism to be outside of Islam and, in fact, based on his Western, Christian background comes to the conclusion that Alevism shares more similarities with Christianity. Trowbridge concludes by encouraging other missionaries to help Alevis find their way back to the essence of their belief, Christianity.

7. Mustafa Kemal, also known as "Atatürk" (meaning "Father of the Turks"), was the founder of modern, secular Turkey in 1923.

8. Schielke (2012), who studied non-believers in Egypt, found that his participants held a similar idea, putting their "belief" in human judgment rather than a divine presence. All of his participants who self-identified as non-believers also considered themselves to be secularists. The idea of putting belief in human agency above all can therefore be seen in both believers and non-believers.

9. A cemevi is a place where Alevis conduct their religious ceremonies. It can be described as a "place of worship," though some prefer to see it as more of a "community center" (Köse, 2012)

10. Irène Mélikoff, is credited for "popularizing" the association the term "heterodox" has with Alevis and as such "Alevi intellectuals" drew upon her work (Langer \& Simon, 2008).

11. In the literature, as well as in daily life, saz and bağlama are generally used interchangeably to refer to the same instrument. I have adopted this way of referencing in my writing, as well. The bağlama is a "long-stemmed, large-bowled string instrument that has come symbolically to represent...folk music" (Bryant, 2005, p. 222). The Turkish folksongs played on the saz are called türkü meaning "belonging to the Turks" (Sels, 2014).

12. Other practices that they do not follow are "Zekat [Offerings], Hacc [Hajj/Pilgrimage to Mecca] and Kelime-I Şahadet [Confession of Faith]” (Hanoğlu, 2016, p. 47).

13. Pir Sultan Abdal (16th century) "fought against Ottoman authoritarianism and was ultimately hung for his resistance" (Bates, 2011, p. 7). He is an Alevi known as being a martyr, dervish, rebel, and poet (Karolewski, 2008; Koerbin, 2011b). See Koerbin (2011b) for a version of the story of Pir Sultan Abdal in English.

14. Hacı Bektaş Veli (13th century) "was the patron saint and uniting force of the Turkmen communities in Eastern Anatolia and present-day Iran" (Bates, 2011, p.7).

15. Also known as minstrels.

16. In Turkish "ler" and "lar" are put at the end to pluralize the word, however I have opted for marking the plural with an "s" for a more flowing paper.

17. The dissertation of Koerbin (2011a) offers an extensive number of works by the poet Pir Sultan Abdal that have been translated into English.

18. Though I am not Alevi, my father's side is Turkish. Growing up in the United States I was not familiar with Turkish folksongs or the saz. Nobody in my family, to my knowledge, plays the saz. I was intrigued by the saz's sound, and along with a previous appreciation of musical instruments I decided to learn to play during my 2 years living in Istanbul.

19. During my fieldwork, my interviews were conducted mostly in Turkish and occasionally in English. Those that were done in Turkish have been translated either by myself or with the help of my father, to whom I owe a big thanks.

20. The Sivas Massacre, also known as Madımak (the name of the hotel), was a tragedy that claimed the lives of 37 Alevis (intellectuals, namely artists, writers, musicians) who were staying at the hotel for the festival honoring Pir Sultan Abdal when a "mob" of "Sunni fundamentalists" set fire to it (Yildiz \& Verkuyten, 2011, p. 245). 
21. I would like to thank Dimitris Gianniodis for granting me permission to use his video, as well as those featured in the video, for graciously allowing me to put it in this paper.

\section{References}

Adams, R. E. (2016). The Turkish Bağlama: A sacred symbol of Alevi Identity. Nota Bene: Canadian Undergraduate Journal of Musicology, 9(1), 4, http://ir.lib.uwo.ca/notabene/vol9/ iss $1 / 4$.

Asad, T. (2009). The idea of an anthropology of Islam. Qui Parle, 17(2), 1-30, https://doi.org/ 10.5250/quiparle.17.2.1.

Atasoy, Y. (2011). Two imaginaries of citizenship in Turkey: The republican and "ethical" models. International Journal of Politics, Culture, and Society, 24(3/4), 105-123, https://doi.org/10.1007/s10767-011-9115-y.

Bates, E. (2011). Music in Turkey: Experiencing music, expressing culture. New York, NY: Oxford University Press.

Bates, E. (2012). The social life of musical instruments. Ethnomusicology, 56(3), 363-395, https://doi.org/10.5406/ethnomusicology.56.3.0363.

Bryant, R. (2005). The soul dance into the body: Nation and improvisation in Istanbul. American Ethnologist, 32(2), 222-238, https://doi.org/10.1525/ae.2005.32.2.222.

Dressler, M. (2003). Alevi poetry in the twentieth century: The Fusion of political and religious identities. Alif: Journal of Contemporary Poetics, 23, 109-154, https://doi.org/10.2307/ 1350078.

Dressler, M. (2005). Inventing orthodoxy: Competing claims for authority and legitimacy in the Ottoman-Safavid Conflict. In H. T. Karateke \& M. Reinkowski (Eds.), Legitimizing the Order. The Ottoman rhetoric of state power (pp. 151-173). Leiden, Netherlands: Brill. URL:https://www.academia.edu/6284359/ Inventing_Orthodoxy_Competing_Claims_for_Autority_and_Legitimacy_in_the_OttomanSafavid_Conflict.

Dressler, M. (2013). Writing religion: The making of Turkish Alevi Islam. Oxford, England: Oxford University Press. https://doi.org/10.1093/acprof:oso/9780199969401.001.0001.

Dressler, M. (2015). Turkish politics of doxa: Otherizing the Alevis as heterodox. Philosophy and Social Criticism, 41, 445-451.

Erol, A. (2008). Reconstructing cultural identity in diaspora: Musical practices of the Toronto Alevi community. In U. Hemetek \& H. Sağlam (Eds.), Music from Turkey in the Diaspora (pp. 151-161). Vienna, Austria: Institut für Volksmusikforschung und Ethnomusikologie.

Erol, A. (2010). Re-imagining identity: The transformation of the Alevi Semah. Middle Eastern Studies, 46(3), 375-387, https://doi.org/10.1080/00263201003682982.

Erol, A. (2012). Identity, migration and transnationalism: Expressive cultural practices of the Toronto Alevi community. Journal of Ethnic and Migration Studies, 38(5), 833-849, 849.https://doi.org/10.1080/1369183X.2012.668025.

Hanoğlu, H. (2016). An introduction to Alevism: Roots and practices. In T. Issa (Ed.), Alevis in Europe: Voices of Migration, Culture and Identity (pp. 40-54). Oxon, England: Routledge.

Karolewski, J. (2008). What is heterodox about Alevism? The development of anti-Alevi discrimination and resentment. Die Welt Des Islams, 48(3/4), 434-456, https://doi.org/ 10.1163/157006008X364767.

Koerbin, P. V. (2011a). I am Pir Sultan Abdal : A hermeneutical study of the self-naming tradition (mahlas) in Turkish Alevi lyric song (deyiş). University of Western Sydney. Doctoral dissertation.

Koerbin, P. V. (2011b). Pir Sultan Abdal: Encounters with persona in Alevi lyric song. Oral Tradition, 26(1), 191-220, https://doi.org/10.1353/ort.2011.0005.

Köse, T. (2012). Ideological or religious? Contending visions on the future of Alevi identity. Identities, 19(5), 576-596. 
Langer, R., \& Simon, U. (2008). The dynamics of orthodoxy and heterodoxy. Dealing with divergence in Muslim discourses and Islamic studies. Die Welt Des Islams, 48(3/4), 273-288, http://www.jstor.org/stable/27798270.

Lord, C. (2017). Between Islam and the nation; Nation-building, the ulama and Alevi identity in Turkey. Nations and Nationalism, 23, 48-67, https://doi.org/10.1111/nana.12238.

Özkul, D. (2015). Alevi "openings" and politicization of the "Alevi issue" during the AKP rule. Turkish Studies, 16(1), 80-96, https://doi.org/10.1080/14683849.2015.1022722.

Pinkert, M. T. (2016). A voice of their own: Music and social cohesion in Turkish Alevi life. University of Maryland. Doctoral dissertation.

Ross, A. (2016). Minorities and migrant identities in contemporary Europe. In T. Issa (Ed.), Alevis in Europe: Voices of migration, culture and identity (pp. 253-267). Abingdon, Oxon, England: Routledge.

Sels, L. (2014). Türkü and Halay between Ghent and Turkey: An ethnographic study of Turkish folk music in a transnational context. Ghent University. Faculty of Arts and Philosophy. Doctoral dissertation.

Şentürk, B. (2016). Urbanisation, socialist movements and the emergence of Alevi identity in the 1970s. In T. Issa (Ed.), Alevis in Europe: Voices of Migration, Culture and Identity (pp. 120-135). Oxon, England: Routledge.

Schielke, S. (2012). Being a nonbeliever in a time of Islamic revival: Trajectories of doubt and certainty in contemporary Egypt. International Journal of Middle East Studies, 44(2), 301-320, https://doi.org/10.1017/S0020743812000062.

Sökefeld, M. (2004). Religion or culture? Concepts of identity in the Alevi diaspora. In W. Kokot, K. Tölölyan, \& C. Alfonso (Eds.), Diaspora, identity, and religion. New directions in theory and research. Routledge research in transnationalism (pp. 133-155). London, England: Routledge.

Taş, H. (2015). Can the Alevis speak? The politics of representation in early writings on Alevism. Islam and Christian-Muslim Relations, 26(3), 325-338, https://doi.org/10.1080/ 09596410.2015.1045177.

Turkey: Sunni-alevis relationship remains contentious in turkey. (2010, May 20). Asia News Monitor. Retrieved from http://search.proquest.com/docview/ 1027450734 ? accountid $=17215$

Yildiz, A., \& Verkuyten, M. (2011). Inclusive victimhood: Social identity and the politicization of collective trauma among Turkey's Alevis in Western Europe. Peace and Conflict: Journal of Peace Psychology, 17(3), 243-269, https://doi.org/10.1080/10781919.2011.587175.

Zarinebaf-Shahr, F. (1997). Qizilbash heresy and rebellion in Ottoman Anatolia during the sixteenth century. Anatolia Moderna, 7, 1-15. 